\title{
Estrogen, Estrogen Receptor and Lung Cancer
}

\author{
Li-Han Hsu ${ }^{1,2,3}$, Nei-Min Chu ${ }^{4}$ and Shu-Huei Kao ${ }^{1,5, *}$ \\ 1 Ph.D. Program in Medical Biotechnology, College of Medical Science and Technology, \\ Taipei Medical University, Taipei 110, Taiwan; lhhsu@kfsyscc.org \\ 2 Division of Pulmonary and Critical Care Medicine, Sun Yat-Sen Cancer Center, Taipei 112, Taiwan \\ 3 Department of Medicine, National Yang-Ming University Medical School, Taipei 112, Taiwan \\ 4 Department of Medical Oncology, Sun Yat-Sen Cancer Center, Taipei 112, Taiwan; nmchu@kfsyscc.org \\ 5 School of Medical Laboratory Science and Biotechnology, College of Medical Science and Technology, \\ Taipei Medical University, Taipei 110, Taiwan \\ * Correspondence: kaosh@tmu.edu.tw; Tel.: +886-2-2736-1661 (ext.3317); Fax: +886-2-2732-4510
}

Received: 25 June 2017; Accepted: 3 August 2017; Published: 5 August 2017

\begin{abstract}
Estrogen has been postulated as a contributor for lung cancer development and progression. We reviewed the current knowledge about the expression and prognostic implications of the estrogen receptors (ER) in lung cancer, the effect and signaling pathway of estrogen on lung cancer, the hormone replacement therapy and lung cancer risk and survival, the mechanistic relationship between the ER and the epidermal growth factor receptor (EGFR), and the relevant clinical trials combining the ER antagonist and the EGFR antagonist, to investigate the role of estrogen in lung cancer. Estrogen and its receptor have the potential to become a prognosticator and a therapeutic target in lung cancer. On the other hand, tobacco smoking aggravates the effect of estrogen and endocrine disruptive chemicals from the environment targeting ER may well contribute to the lung carcinogenesis. They have gradually become important issues in the course of preventive medicine.
\end{abstract}

Keywords: epidermal growth factor receptor; estrogen; estrogen receptor; hormone; lung cancer; lung adenocarcinoma

\section{Introduction}

Estrogens are steroid hormones. 17- $\beta$-Estradiol (E2) is the primary reproductive hormone synthesized in the ovary under the stimulation of the follicular stimulating hormone and the luteinizing hormone [1-4]. Estrone and estriol are mostly synthesized in the liver from E2. The functions of estrogen and its receptors in reproductive organs, especially in a female, have been known for several decades. The importance of the estrogen signaling pathway in various physiologic, pathologic functions and carcinogenesis has also been extensively investigated, especially in the context of breast cancer.

There are two types of classical estrogen receptor (ER). ER alpha (ER $\alpha$, also known as ESR1), product of genes on chromosome 6, first cloned in 1986 and distributed in breast, ovary, and endometrium. ER beta (ER $\beta$, also known as ESR2), product of genes on chromosome 14, discovered in 1996 [5], with a wider distribution including the bone, brain, colon, endothelium, kidney, lung, ovary, prostate, and testes. They share similar structures and are composed of five domains. The A/B domain is the site of the transcriptional activation, with the coactivator, AF-1. The C-domain is the DNA-binding site. The D-domain hinge contains a nuclear localization signal. The E-domain is the ligand binding domain and the site of the transcriptional activation, with the coactivator, AF- 2 . The F-domain may play a complex regulatory role. The 55\% homology between the ER $\alpha$ and ER $\beta$ in the ligand binding domain results in the variable affinities. While both exhibit similar affinities to $\mathrm{E} 2, \mathrm{ER} \alpha$ has a higher affinity to estrone and ER $\beta$ has a higher affinity to estriol. In addition to the 
wide-type ERs, several splicing variants or isoforms of the ERs have been described with variable DNA- or ligand-binding properties.

Upon binding with estrogen, the ERs form either homo- or heterodimers and bind to the estrogen responsive element, the ERE within the promoter of a target gene, and then regulate its transcription in the case of the genomic pathway. ERs may also regulate gene expression via the binding to other transcription factors such as the activator protein 1, AP-1 or the stimulating protein 1, Sp1. On the other hand, ERs may translocate to the membrane, where they may mediate a non-genomic pathway that results in more rapid responses, such as the activation of protein kinase, the production of second messengers, or the regulation of ion channels.

Lung cancer is a leading cause of cancer-related mortality worldwide, including Taiwan. Studies conducted in Western countries estimated that $85-90 \%$ of lung cancer cases were attributed to smoking [6,7]. Although $80 \%$ of female lung cancer patients worldwide have smoked, less than $10 \%$ of Taiwanese women are smokers [8]. In our previous lung cancer study, only $6.4 \%$ of the female patients had smoked cigarettes at some time in their lives [9]. There is a lung adenocarcinoma epidemic with an equal occurrence and prognosis in both genders who have never smoked in Taiwan [10]. Smoking history appeared to be a poor prognostic factor for patients with lung adenocarcinoma, rather than as a risk factor. The low smoking prevalence and high incidence rate of adenocarcinoma constituted distinctive characteristics of lung cancer in Asian countries, and leads to the suggested existence of non-tobacco related risk factors in the pathogenesis of lung adenocarcinoma.

Another study showed a more significant survival advantage for elderly women with lung adenocarcinoma, as compared with their male counterparts [11]. In addition to the inferior survival of elderly male patients attributed to the accumulated adverse effect of a higher prevalent smoking habit, the superior survival of the postmenopausal female patients was possibly due to the less estrogen cancer promoting effect. The premenopausal women, who comprised one-fifth of the non-smoking female patients with lung adenocarcinoma, were found to have had the more advanced disease and a shorter survival rate than the postmenopausal women. The epidemiology results suggest that estrogen adversely affects the prognosis of patients with lung adenocarcinoma.

Estrogen is speculated as playing an important role in lung carcinogenesis [12,13]. In healthy lung tissue, ER $\beta$ is highly expressed in pneumocytes and in the bronchial epithelial cells, and is required for the maintenance of the extracellular matrix of the lung $[14,15]$. The lung tissues of ER $\beta$ null mice were found to have a decreased number of alveoli and a lesser amount of surfactant [16]. Studies of ER deficient mice have shown that $E R \alpha$ mediates the determination of the alveolar number and the surface area while ER $\beta$ affects the lung tissue elastic recoil [17]. Estrogen receptors (ER) are consistently found in lung cancer tissues and cell lines, especially adenocarcinoma, and mostly in the form of the ER $\beta$ [18-21]. Estrogen has been reported to adversely affect the prognosis of lung cancer patients [22-30]. However, there are several studies with conflicting results about the effect of estrogen on the risk and/or survival of lung cancer [31-36].

We demonstrated ER $\beta$ was the predominant ER in the A549 and PE089 lung cancer cell lines, and malignant pleural effusions from the patients with lung adenocarcinoma. Osteopontin (OPN) is a small integrin-binding ligand $N$-linked glycoprotein regulating signaling pathways involved in tumor progression and metastasis [37-39]. Enhanced OPN expression has been noted in the plasma of advanced lung cancer patients, and OPN has also been speculated to be involved in the formation of malignant pleural effusion $[40,41]$. Estrogen up-regulated the OPN expression and promoted lung cancer cell migration via the ER $\beta$ activation of the MEK/ERK signaling pathway. An additive effect of the ER antagonist and the epidermal growth factor receptor (EGFR) antagonist on the inhibition of lung cancer cell migration was also observed. Osteopontin supposedly contributes to the cross-talk between the ER and EGFR signaling pathways [11]. In current clinical practice, breast cancer survivors offer a unique patient cohort to evaluate the effect of anti-estrogen on the survival of lung cancer patients $[42,43]$. We have evaluated the outcome of 26 women who have had second primary lung cancer among 6361 breast cancer patients diagnosed and treated between January 2000, and December 
2009, at Sun Yat-Sen Cancer Center and found that the patients who were treated with anti-estrogens for breast cancer had a longer cancer-specific survival rate than those without anti-estrogens [44]. Multivariate analysis confirmed that the anti-estrogen treatment was an independent prognostic factor. These findings reinforced the evidence that estrogen had, in fact, contributed to the lung cancer progression.

This review aims to summarize the current knowledge with regard to the expression and prognostic implications of the ERs in lung cancer, the effect and signaling pathway of estrogen on lung cancer, the hormone replacement therapy and lung cancer risk and survival, the mechanistic relationship between the ER and the EGFR, and the relevant clinical trials combining the ER antagonist and the EGFR antagonist, to investigate the role of estrogen in lung cancer. Interaction between tobacco smoking and estrogen, and the role of endocrine disruptive chemicals targeting ER from the environment in the lung carcinogenesis were also discussed from the viewpoint of preventive medicine. As small cell lung cancer (SCLC) is a distinct neuroendocrine tumor, composed of about $10 \%$ to $15 \%$ of lung cancer, and the association between estrogen and SCLC was scarcely studied and mostly obsolete $[45,46]$. The following issues will focus on the non-small cell lung cancer (NSCLC), being mostly adenocarcinoma.

\section{Estrogen Receptor in Lung Cancer}

Baik et al. have systemically reviewed the detection rates of the ER $\alpha$ and ER $\beta$ in lung cancer $[47,48]$. For the ER $\alpha$, the detection rate using $1 \mathrm{D} 5$ with the epitope in $\mathrm{N}$-terminus is $0 \%$ to $55 \%$, in contrast with $36 \%$ to $84 \%$ using HC-20 with the epitope in C-terminus, and $0 \%$ to $78 \%$ using $6 \mathrm{~F} 11$ for the full length. For the ER $\beta$, the detection rate using $\mathrm{H}-150$ or $14 \mathrm{C} 8$ with the epitope in N-terminus is $49 \%$ to $98 \%$, and $16 \%$ to $86 \%$, respectively. The detection rate is $9 \%$ to $84 \%$ using PPG5/10 with the epitope in the C-terminus. The results were variable. Such an inconsistency may be due to the differences in the methodology, i.e., which antibody is used, heterogeneous definitions of positivity, and various patient populations, i.e., pathology, stage, gender, and smoking history [47-49]. The ER $\alpha$ antibody with epitope in the C-terminus reported a higher detection rate than that with epitope in the N-terminus in the NSCLC, and was mostly cytoplasm-located. The ER $\alpha$ probably occurs as the $\mathrm{N}$-terminal deleted mutants in the NSCLC and lacks the nuclear localization [47-49]. Unlike the ER $\alpha$, both of the full-length and splicing variants of the ER $\beta$ exist in the NSCLC cells. A strong expression of the ER $\beta$ was observed in the cytoplasm as well as the nucleus. Standardized measurement, i.e., which antibody was used, or a different approach from immunohistochemistry, e.g., western blot, mRNA expression by real time quantitative PCR, is necessary to make the ERs as useful biomarkers in the future.

Estrogen receptor $\beta$ appears to be the predominant form in lung cancer from the literature [18-21]. Five splicing variants had been identified with ER $\beta 1$ being the only full-length receptor able to bind ligand and form homodimers in human. The rest of the isoforms are inactive, but they can form heterodimers with ER $\beta 1$ to regulate its transcriptional activity [50].

The expressions of ER $\alpha$ and ER $\beta$ as a prognosticator for NSCLC have been reported in several studies $[20,21,51-64]$ (Table 1). Contrary to that in breast cancer, ER $\alpha$ in lung cancer was mainly observed in the cytoplasm and associated with a poor prognosis. Most reports found that the nuclear ER $\beta$ was predictive of a better prognosis, and the cytoplasmic ER $\beta$ was associated with a poor prognosis $[47,48]$. Nonetheless, opposing results have also been reported $[54,60,62,63,65,66]$. Co-expression of the cytoplasmic ER $\beta$ and the nuclear ER $\beta$ that had been reported correlated with a poor survival rate when compared to those without co-expression [67]. The nuclear and cytoplasmic ERs may have a distinct function and affect the prognosis differentially via the genomic or non-genomic pathway. ER $\beta$ has also been shown to localize with the mitochondria in a ligand-dependent or -independent manner and can affect the bioenergetics and anti-apoptotic signaling. Mitochondrial $\mathrm{ER} \beta$ sequesters Bad and inhibit Bad-Bcl-XL, and Bad-Bcl-2 interactions, to protect against apoptosis, thereby suggesting its value as a new therapeutic target $[27,68,69]$. Further study is warranted to 
analyze the function of different ER $\beta$ isoforms and their cellular localization, which is essential to completely understand the role of the ER $\beta$ in lung cancer. According to the study of Kadota, although nuclear ER $\alpha$ expression was observed in only $17 \%$ of the patients with pT1a lung adenocarcinomas, it was an independent predictor of recurrence [61]. The nuclear ER $\alpha$ expression positively correlated with the tumoral Fox $\mathrm{P}^{+}$lymphocytes, and poor prognostic immune microenvironments.

Table 1. Estrogen receptor (ER) detected by immune-histochemical stain as prognosticators in NSCLC.

\begin{tabular}{cccc}
\hline References & ER Subtype & Location & Prognosis \\
\hline Kawai 2005 [20] & $\alpha$ & Cytoplasm & Worse \\
& $\beta$ & Nucleus & Better \\
Schwartz 2005 [21] & $\beta$ & Non-specified & Better (male) \\
Wu 2005 [51] & $\beta$ & Nucleus & Worse (female) \\
Skov 2005 [52] & $\beta$ & Nucleus & Better \\
& & & Worse (female) \\
Nose 2009 [53] & $\alpha$ & Cytoplasm & Worse \\
& $\beta$ & Nucleus & Better \\
Raso 2009 [54] & $\beta$ & Nucleus & Worse \\
Stabile 2011 [55] & $\beta$ & Cytoplasm & Worse \\
Rouquette 2012 [56] & $\alpha$ & Nucleus & Better \\
Rades 2012 [57] & $\alpha$ & Non-specified & Worse \\
Karlsson 2012 [58] & $\beta$ & Nucleus & Better \\
Navaratnam 2012 [59] & $\beta 1$ & Nucleus & Better in earlier stage \\
Liu 2013 [60] & $\beta 2,5$ & Cytoplasm & Worse in later stage \\
Kadota 2015 [61] & $\alpha$ & Nucleus & Better \\
Liu 2015 [62] & $\beta$ & Cytoplasm & Worse \\
Skjefstad 2016 [63] & $\beta$ & Nucleus & Better \\
Tanaka 2016 [64] & $\beta$ & Non-specified & Worse (female) \\
\hline & $*$ Not significant but with a trend & Worse (male) \\
\hline
\end{tabular}

The G-protein-coupled estrogen receptor (GPER), discovered in 2005, was proposed to be involved in the cancer cell proliferation, migration and invasion, and acts as a modulator of the neoplastic transformation $[4,70,71]$. It is not only located in the cell membrane, it has also been detected in the Golgi apparatus and endoplasmic reticulum [72,73]. Increased expression of the GPER was observed in the lung cancer cell lines as well as the human and mice lung cancer tissue, and more was located in the cytoplasm [74,75]. Paradoxically, the antagonists/modulators of the classical estrogen receptors such as tamoxifen, raloxifen and fulvestrant, were found to be the GPER agonists [70].

In contrast with GPER, the classical ERs do not contain a hydrophobic part that may serve as a transmembrane domain. However, the presence of ERs in the membrane of somatic and cancer cells have been reported. The membrane translocation of the ERs is mediated by the SRC family of tyrosine kinase [76]. Specific motifs and modifications are required. The knowledge on how the classical ERs translocate to the membrane together with the knowledge on the GPER action, and the interactions between the GPER and the classical ERs is of the greatest importance to understand the membrane-associated non-genomic pathways of estrogen.

In premenopausal women, estrogens produced by their ovaries play a major role in the female reproductive organs through the ER $\alpha$. In postmenopausal women, however, estrogens produced/activated by peripherally localized estrogen-metabolizing enzymes, such as aromatase, which converts androgen into estrogens, are thought to play physiologically and pathologically important roles in various organs through the ER $\beta$, distributing systemically [77]. Estrogen can be synthesized in situ in lung cancer. Ikeda et al. measured the estrogen concentrations in the noncancerous peripheral lung tissue using liquid chromatography/electrospray tandem mass spectrometry in the postmenopausal female patients with synchronous multiple lung adenocarcinomas, 
and found a significantly higher level than the control cases with a single lung adenocarcinoma [78] (Figure 1). Our study of the malignant pleural effusion of lung adenocarcinoma revealed that some postmenopausal women had extraordinarily high pleural fluid estradiol concentrations, and there was no correlation between the pleural fluid concentrations of estradiol and the vascular endothelial growth factor, a marker of pleural vascular hyperpermeability [79]. In addition, the EGFR wild-type lung adenocarcinoma is probably an estrogen-dependent carcinoma, as a higher expression and potent poor prognosticator of aromatase and the ER $\beta$ in the group [62].

Thyroid transcription factor 1 (TTF-1) expression, as a lineage marker of the terminal respiratory unit, is helpful to distinguish the primary (TTF-1 positive) from the metastatic (usually TTF1 negative) lung adenocarcinoma, the pleural lung carcinoma (TTF-1 positive) from the mesothelioma [80]. The TTF-1-positive adenocarcinomas had a statistically significant prevalence of the female, non-smoker, and associated with the EGFR mutation [81,82]. The ER and TTF-1 immunoreactivity is commonly used as a means of distinguishing breast carcinomas from the adenocarcinomas of other primary sites, including the lung, but mostly using the antibody of the ER $\alpha$. The TTF-1 positivity may be associated with the ER $\beta$ expression in lung adenocarcinoma with clinical significance, which therefore deserves further study [83].

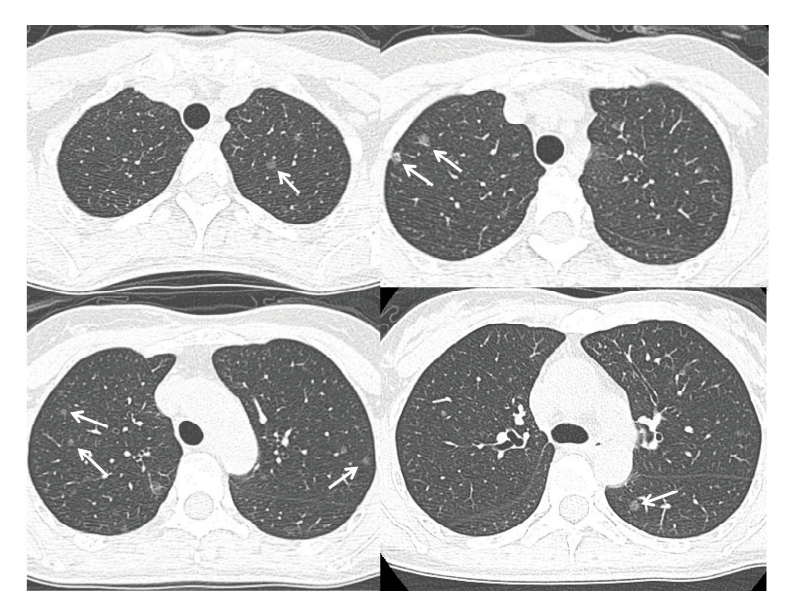

Figure 1. A 48 year-old non-smoking woman was found to have multiple subcentimetre ground glass opacities (arrows) in her bilateral lungs on a low-dose CT screening. Video-assisted thoracoscopic surgery with a right upper lobe wedge resection confirmed the diagnosis of synchronous multiple lung adenocarcinomas harboring the EGFR wild-type.

\section{Hormone Replacement Therapy and Lung Cancer Risk and Survival}

There were also controversies in the relationship between the hormone replacement therapy (HRT) and lung cancer. Although most studies reported estrogen or HRT adversely affected the prognosis of lung cancer patients [22-30], some reported HRT decreased the risk and favorably affected the prognosis [31-36]. In the Women's Health Initiative Trial, HRT using estrogen plus progestin in postmenopausal women did not increase the incidence of lung cancer, but increased the risk $(60 \%)$ of dying from NSCLC [29]. Unlike the use of estrogen plus progestin, the usage of conjugated equine estrogen alone did not increase the incidence or death from lung cancer [36]. In another Vitamins and Lifestyle Study, postmenopausal women taking estrogen plus progestin were reported to have a $50 \%$ increased risk of incident lung cancer for usage of 10 years or longer and an advanced stage at diagnosis [30]. Greiser et al. made a systemic review and meta-analysis from 18 studies for the risk of lung cancer after HRT [84]. Ever use of HRT in non-smoking women may well increase the risk of lung adenocarcinoma. Data from the randomized controlled trials suggested that estrogen/progestin therapy increased the lung cancer mortality. The increased risk of death from lung cancer during the 
estrogen plus progestin usage in the Women's Health Initiative Trial was recently reported attenuated after the discontinuation of the medication in a 14-year cumulative follow-up [85].

Siegfried and Stabile provided explanations for the discrepancy of the HRT effect [49]. Different influences of estrogen on the balance of differentiation induction and proliferation in normal lung epithelium and malignant epithelium have been reported [55]. Compared with the matched normal lung tissues, ER $\beta$ is overexpressed in lung cancer, which could lead to an abnormal response to estrogen. The ability of the immune system to reject the malignant lung tissues during the early process could be enhanced by HRT [49] and related to a different level of ER expression [61,86,87]. Exogenous hormone usage reduces the local estrogen production by inhibiting the pulmonary aromatase expression. The exact HRT used, i.e., type, duration, timing, and adjusted covariates may modulate the effects of HRT. More specifically designed studies to address the HRT type, smoking, and histology, are therefore warranted to arrive at the more definitive conclusions. However, since the HRT is now recommended to be used for a limited duration, its effects on lung cancer risk or survival may be less pronounced in the future.

\section{ER as Targets for Lung Cancer Therapy and Relationship with EGFR}

Estradiol is locally produced in the NSCLC mainly by aromatase, which is localized in both the epithelial cell components of lung tumors as well as in the infiltrating macrophages; even exclusively confined to the inflammatory cells infiltrated in the pre-neoplastic and neoplastic areas in some of the animal models $[88,89]$. Patients whose tumors harbored a higher expression of aromatase and ER $\beta$ have a lower survival rate, especially in postmenopausal women $[13,90]$. The use of selective ER modulators and/or aromatase inhibitors have been reported to be clinically effective in the NSCLC that are positive for both the ER and aromatase [91,92]. Recently, Hamilton et al. utilized a quantitative high-throughput screening of approved drugs, and identified the ER antagonist, fulvestrant, as being capable of reducing the mesenchymal features of lung cancer cells and sensitize to the cytotoxic effect of the chemotherapy [93].

As aforementioned, the activities of the ER $\beta$ could be genomic or non-genomic [94] (Figure 2). The estrogen-ER $\beta$ complex binds to the nuclear estrogen response elements directly or through the transcription factor, to promote the gene expression. Estrogen also combines with membrane-bound ER $\beta$ to activate the cytoplasmic signaling pathway and interacts with the EGFR signaling pathways $[95,96]$ (Figure 3). EGFR has been reported to directly phosphorylate ER at specific serine residues (a ligand-independent signaling) in $87.5 \%$ of the ER-positive lung tumors [96,97]. In addition to the MEK/ERK signaling pathway, estrogen also activates the PI3K/AKT signaling pathway, another downstream pathway of the EGFR activation, to promote lung cancer cell metastasis through epithelial mesenchymal transition [98]. Other non-genomic activities have also been explored. Fan et al. found a higher ER $\beta$ expression in the lymph node as compared to the primary tumor tissues, and estrogen promotes the lung cancer cell metastasis via the ER $\beta$-mediated up-regulation of the matrix-metalloproteinase-2 [99]. In the mRNA analyses, when comparing the high versus low ER $\beta$ expressing tumors by the group of Siegfried and Stabile, the top differentially expressed genes in the high ER $\beta$ tumors involved the fibroblast growth factor signaling and the human embryonic stem cell pluripotency [100].

ER and EGFR, as targets for dual lung cancer therapy, have been studied. A combination of the ER antagonist and the EGFR tyrosine kinase inhibitor has been shown to decrease cell proliferation and tumor growth more than one individual treatment in both in vitro and in vivo studies $[53,97,101,102]$. In the NSCLC cell lines, the EGFR protein expression was down-regulated in response to estrogen and up-regulated in response to anti-estrogens in vitro. Conversely, the ER $\beta$ expression is decreased in response to the epidermal growth factor and increased in response to gefitinib [101]. A strong association has been reported between the expression of the ER $\beta$ and EGFR mutations in lung adenocarcinoma $[53,54,103,104]$. These studies have provided evidence of a functional interaction between the ER and EGFR pathways in lung cancer and have supported a rationale to use the combined therapy $[95,105]$. 


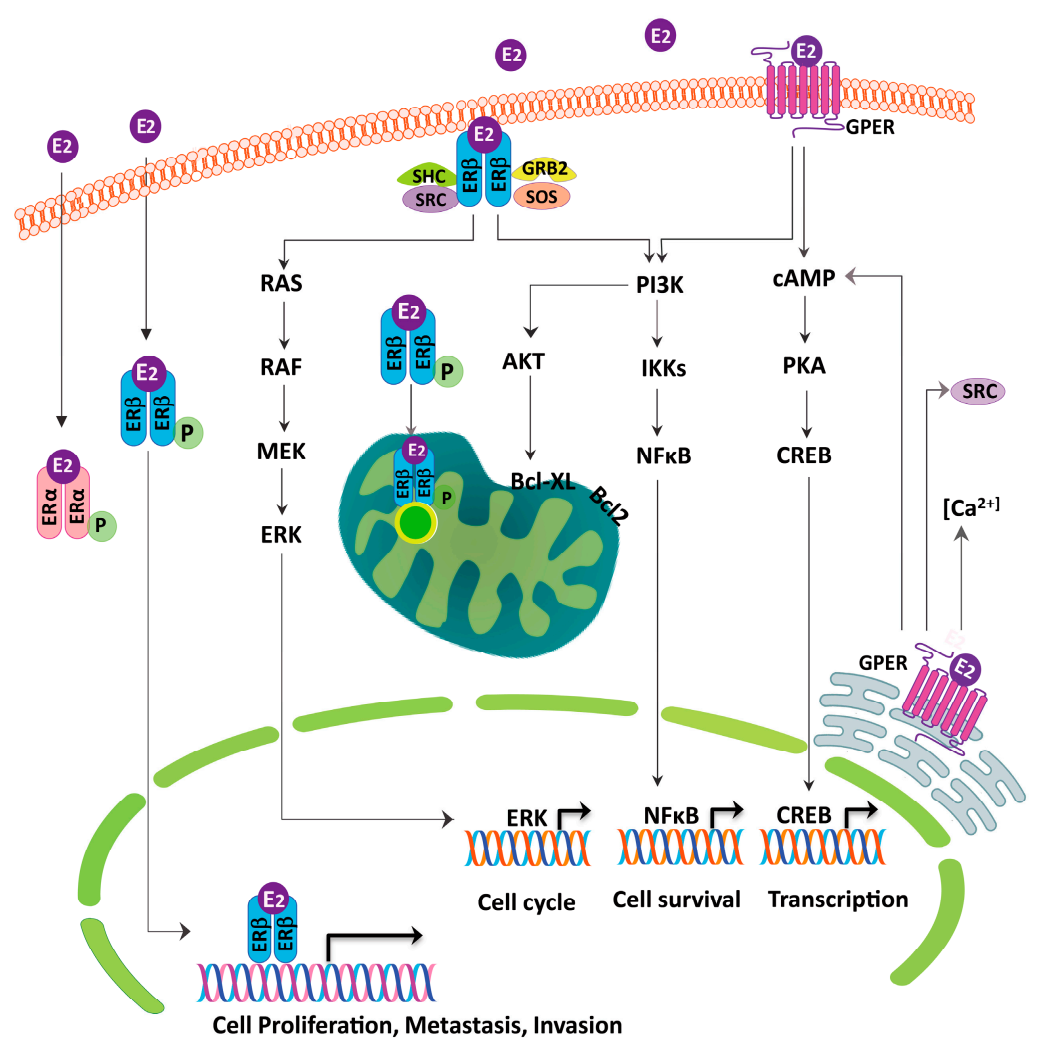

Figure 2. The putative role of the estrogen receptor in regulating the lung cancer cells growth. The estrogen receptor $\beta$ (ER $\beta)$ appears to be the predominant form in lung cancer and is present in the cytoplasm, nucleus, mitochondria and plasma membrane. The ER $\beta$ has been found to activate the PI3K/IKK/NFKB, PI3K/AKT/Bcl-XL and the RAS/RAF/MEK/ERK signaling pathways to regulate the cell proliferation, invasion, metastasis, mitochondrial biogenesis and anti-apoptosis. The G-protein-coupled estrogen receptor (GPER) activates the cAMP/PKA/CREB and the PI3K/IKK/NFKB signaling pathways and acts as a modulator of the neoplastic transformation.

The available strategies to target the estrogen signaling pathway include the aromatase inhibitors, the reversible nonsteroidal agents (e.g., letrozole, anastrozole) or the irreversible steroidal inactivator (e.g., exemestane), the nonsteroidal elective ER modulator (e.g., tamoxifen, raloxifene), and the ER antagonists (e.g., fulvestrant) [47]. Giovannini et al. reported that the additional effect of letrozole in a patient with lung adenocarcinoma and scalp metastasis persisted on gefitinib [106]. A pilot study revealed that treatment combining the gefitinib and fulvestrant for postmenopausal women with advanced NSCLC was well-tolerated and demonstrated a result [107]. Several phase II clinical trials are currently ongoing to investigate their effects on advanced NSCLC, mostly in a second-line setting and combined with the EGFR tyrosine kinase inhibitor [108] (Table 2). Some studies have included correlative tissue analysis of the ER and the progesterone receptor status to evaluate their role as a predictor of response. Besides the treatment strategies through inhibiting estrogen synthesis or blocking its effect, dexamethasone has been demonstrated to induce the estrogen sulfotransferase to decreases the estradiol levels in tumor tissues and suppress the A549 xenograft tumor growth [109,110].

No significant difference in the clinicopathological characteristic between the ER $\beta$-positive and ER $\beta$-negative lung adenocarcinoma has been mentioned, except some reported that the ER expression correlated with the tumor differentiation [111]. Detailed pathologic examination of the ER $\beta$-positive adenocarcinoma may be necessary to show the genotype-phenotype correlations, similar to those found in the ALK-rearranged or the EGFR-mutated adenocarcinoma [112,113]. Patients with these characteristic histologic features might be good candidates for, and could benefit from, therapy targeting the ER signaling pathways. 
Novel technologies, e.g., next generation DNA sequencing, epigenetics, transcriptomics, proteomics, and metabolomics, can make an abundant contribution in the understanding of lung cancer [114-116]. The Genetic Epidemiological Study of Lung Adenocarcinoma (GELAC) in Taiwan had found that the gene polymorphisms related to the estrogen biosynthesis and metabolism was associated with an increased occurrence of L858R mutation of the EGFR in non-smoking female lung adenocarcinoma patients [117]. The use of HRT may modify the association of protective EGFR single nucleotide polymorphisms (SNPs) with lung adenocarcinoma risk [118]. The EGFR SNPs have a cumulative effect on decreasing the lung adenocarcinoma risk in non-smoking women with HRT. The ER gene SNPs are associated with a lung adenocarcinoma risk in non-smoking women [119]. The joint effects of the ER and EGFR gene SNPs and HRT usage on lung adenocarcinoma risk highlight the gene-environment interaction in lung carcinogenesis.

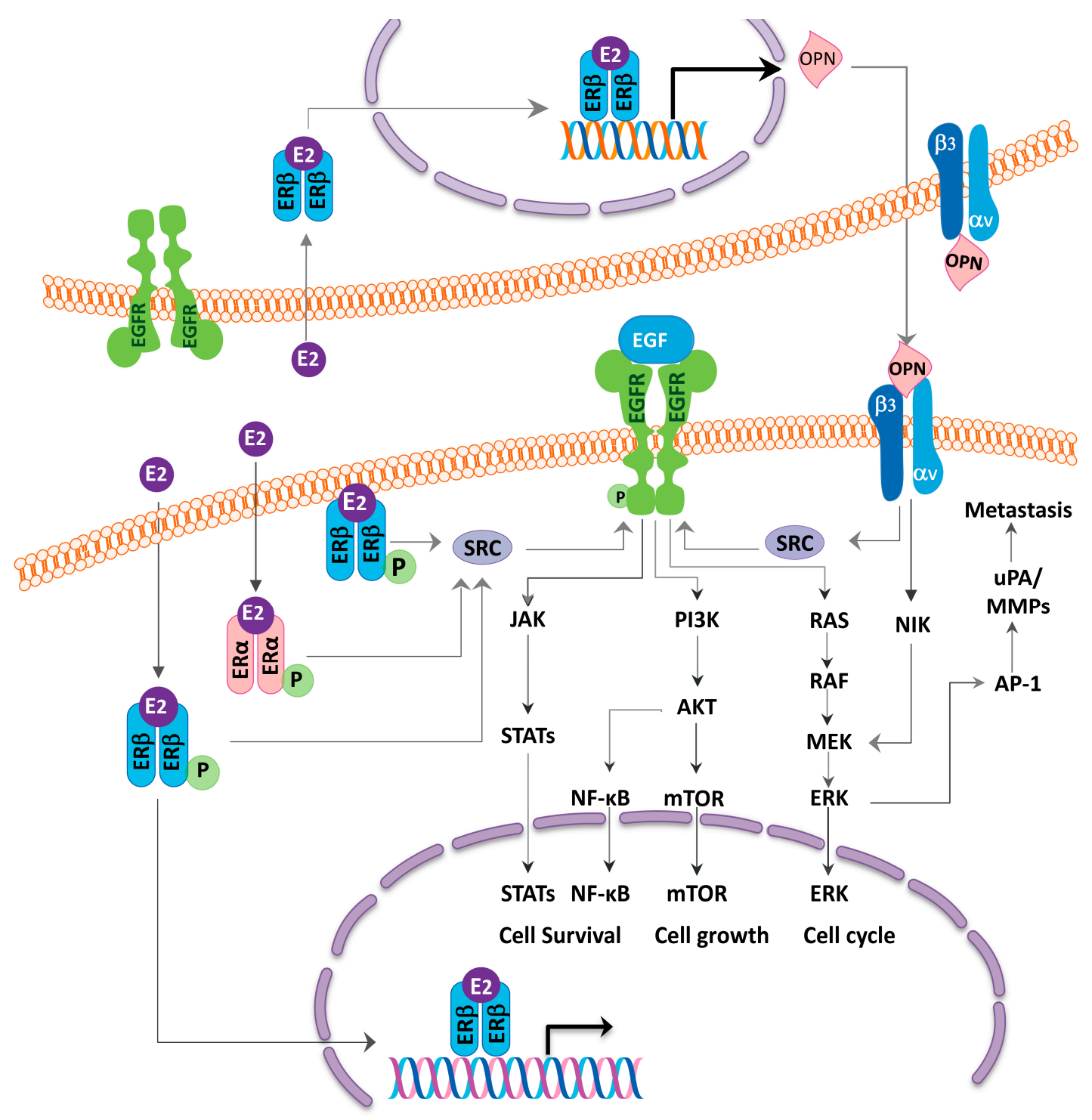

Figure 3. The schematic diagram illustrating the mechanisms of how the estrogen receptor (ER) coordinates with the epidermal growth factor receptor (EGFR) to affect the cell growth in the lung adenocarcinoma. Estrogen stimulates the steroid receptor coactivator (SRC) protein, which in turn, activates the EGFR signaling pathways. In addition, estrogen upregulates the osteopontin (OPN) expression and promotes the lung cancer cell migration via the MEK/ERK signaling pathway. The SRC and OPN contribute to the cross-talk between the ER and the EGFR. 
Table 2. Clinical trials of hormone therapy in advanced NSCLC (http:/ / www.clinicaltrial.gov/, accessed on 11 June 2017).

\begin{tabular}{|c|c|c|c|c|}
\hline Patient Population & Allowed Prior Therapy & Treatment & Correlate Response with Receptors Expression & ClinicalTrials.Gov Identifier \& Status \\
\hline $\begin{array}{l}\text { Stage IIIB or IV NSCLC, } \\
\text { both gender }\end{array}$ & $\geq 1$ prior chemotherapy & Erlotinib + fulvestrant vs. Erlotinib & Yes & NCT00100854 Active, not recruiting (2004 ) \\
\hline $\begin{array}{l}\text { Stage IIIB or IV NSCLC, both } \\
\text { gender, ER or PR positive }\end{array}$ & $\begin{array}{l}\text { Stable disease on erlotinib }>2 \text { months, prior } \\
\text { chemotherapy not defined }\end{array}$ & Erlotinib + fulvestrant (single arm) & Before trial entry & $\begin{array}{c}\text { NCT00592007 Terminated with results } \\
(2007 \sim)\end{array}$ \\
\hline $\begin{array}{l}\text { Stage IIIB or IV, } \\
\text { postmenopausal women }\end{array}$ & $\begin{array}{l}\text { Completed } 4 \text { cycles of induction } \\
\text { platinum-based chemotherapy }\end{array}$ & $\begin{array}{c}\text { Arm B-1. Best supportive care (BSC); } \\
\text { Arm B-2. BSC + bevacizumab; } \\
\text { Arm A-1. Fulvestrant + anastrozole; } \\
\text { Arm A-2. Fulvestrant + anastrazole + } \\
\text { bevacizumab }\end{array}$ & Yes & $\begin{array}{l}\text { NCT00932152 Terminated with results } \\
(2010 \sim)\end{array}$ \\
\hline $\begin{array}{l}\text { Stage III or IV NSCLC, } \\
\text { postmenopausal women }\end{array}$ & $\begin{array}{l}\text { Chemotherapy, } 0-1 \text { line for EGFR mutations } \\
\text { and 1-2 lines for EGFR wild type }\end{array}$ & $\begin{array}{c}\text { Gefitinib + fulvestrant vs. Gefitinib for } \\
\text { EGFR mutations; } \\
\text { Erlotinib + fulvestrant vs. Erlotinib for } \\
\text { EGFR wild type }\end{array}$ & No & NCT01556191 Recruiting (2012 ) \\
\hline $\begin{array}{l}\text { Stage IV NSCLC, } \\
\text { postmenopausal women }\end{array}$ & Phase I dose escalating study & Exemestane + premetrexed, carboplatin & No & NCT01664754 Active, not recruiting (2012 ) \\
\hline $\begin{array}{l}\text { Stage III or IV NSCLC, } \\
\text { postmenopausal women }\end{array}$ & Chemotherapy $1-3$ line & Exemestane (single arm) & No & NCT02666105 Recruiting (2016 ) \\
\hline
\end{tabular}

${ }^{*}$ In the order of study start date. 


\section{Smoking Aggravates the Effect of Estrogen and Endocrine Disruptive Chemical Targeting ER $\beta$ from the Environment May Contribute to the Lung Carcinogenesis}

Tobacco smoking is a common source of complex environmental chemical exposure. More than 3000 chemicals have been identified in tobacco smoke, and many of them are both mutagenic and carcinogenic. There exists a phenomena associated estrogenic metabolism with tobacco combustion. Higher levels of polycyclic aromatic hydrocarbon-derived DNA adducts have been reported in female smokers than in male smokers. Estrogen synergize with the tobacco compounds through the induction of CYP1B1, an enzyme responsible for estrogenic metabolism, which leads to enhanced reactive oxygen species formation and carcinogenesis [4,120-122].

On the other hand, there have been constant concerns about the endocrine disruptive chemical (EDC) in the environment. EDC that have estrogenic properties are known as xenoestrogens. Although their estrogenic activity is weaker than that of estradiol, newer types of EDC and inadvertent forms of exposure continue to be discovered. There is increasing concern about their cumulative effects in carcinogenesis [123]. Endocrine disruptive chemical, e.g., polychlorinated dibenzo- $p$-dioxins, bisphenol A, polychlorinated biphenyls, polybrominated flame retardants, and methoxychlor, were supposed to be a factor in the environment leading to an increased incidence of lung adenocarcinoma $[124,125]$. They target ER $\beta$ with highly variable effects. Their combination with the aryl hydrocarbon receptor and its nuclear translocator could also modulate the ER activity.

Air pollution containing a mixture of particulate matters (PM) and gas contaminants is generally considered to play a role in the development of lung cancer. According to the particles' size, they are categorized into coarse particles ( $<10$ and $>2.5 \mu \mathrm{m}$ in aerodynamic diameter, PM10), fine particles ( $\leq 2.5$ and $>0.1 \mu \mathrm{m}$ in aerodynamic diameter, PM2.5), and ultrafine particles $(\leq 0.1 \mu \mathrm{m})$. In addition to the concern of particle size, the combustion of fossil fuels, road traffic, industries, and waste dumps, are known to emit a number of different mutagens and carcinogens, many of which possess xenoestrogenic activity $[126,127]$. Multifactorial risk assessment incorporating personal exposure history, genetic polymorphisms related to estrogen biosynthesis and metabolism, ER polymorphisms, and biomonitoring data collected from the environment may well identify the population at risk. Collaborations between oncology, system biology, and environmental science will provide an important step to elucidate the etiology of lung cancer and help to make the relevant legislation in the future.

\section{Conclusions}

In addition to the well-known drivers of lung cancer, EGFR (55.7\%), KRAS (5.2\%), BRAF (2.0\%), HER2 (0.7\%) mutations, and EML4-ALK translocation (9.8\%) [128], a body of epidemiological evidence, preclinical in vitro and in vivo studies, and recent data from the clinical trials, support estrogen as an important factor that contributes to lung carcinogenesis, lung cancer growth, metastasis, and affecting the prognosis. Different pathways of the ER activation and interactions with EGFR were proposed. Estrogen, with its receptor, has the potential to be a prognosticator and a therapeutic target in lung cancer. The ER antagonist may well become a new and effective treatment modality for patients with lung adenocarcinoma and an alternative treatment for patients with acquired resistance to the EGFR antagonists $[101,105,129]$. However, there were many conflicting results in the literature that need to be addressed [31-36,130], of which include the standardized measurements of the ER expression before adopting them as a useful biomarker, the mechanisms that underlie the controversy in the effect of hormone replacement therapy, the role of different estrogen and various ER in lung cancer cell proliferation, migration, and invasion, and the pathways involved in their interactions with other mediators. The risk of EDC exposure also raises the concern of genetic and environmental interaction in lung carcinogenesis.

Acknowledgments: The authors would like to offer their sincere thanks to Michael Wise for his help with the English language editing; Yun-Ying Chen and Shiao-Chiu Huang for their assistance with the figures, data and references preparation. 
Author Contributions: Li-Han Hsu and Shu-Huei Kao conceived the paper; Li-Han Hsu and Shu-Huei Kao wrote the paper; Li-Han Hsu, Nei-Min Chu, and Shu-Huei Kao revised the paper.

Conflicts of Interest: The authors declare no conflict of interest.

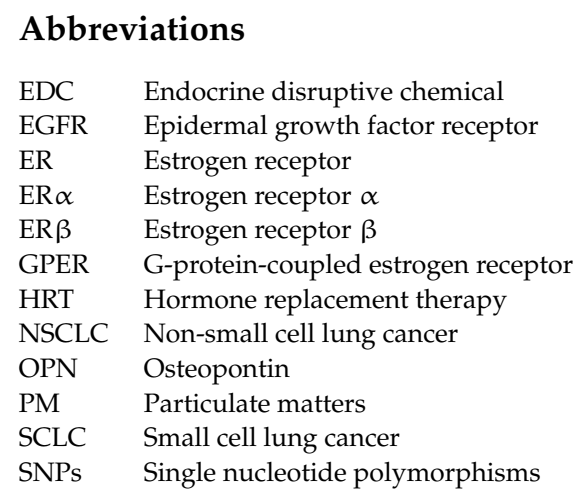

\section{References}

1. Nilsson, S.; Mäkelä, S.; Treuter, E.; Tujague, M.; Thomsen, J.; Andersson, G.; Enmark, E.; Pettersson, K.; Warner, M.; Gustafsson, J.A. Mechanisms of estrogen action. Physiol. Rev. 2001, 81, 1535-1565. [PubMed]

2. Paterni, I.; Granchi, C.; Katzenellenbogen, J.A.; Minutolo, F. Estrogen receptors alpha (ER $\alpha)$ and beta (ER $\beta)$ : Subtype-selective ligands and clinical potential. Steroids 2014, 90, 13-29. [CrossRef] [PubMed]

3. Dostalova, P.; Zatecka, E.; Dvorakova-Hortova, K. Of oestrogens and sperm: A review of the roles of oestrogens and oestrogen receptors in male reproduction. Int. J. Mol. Sci. 2017, 18, 904. [CrossRef] [PubMed]

4. Slowikowski, B.K.; Lianeri, M.; Jagodzinski, P.P. Exploring estrogenic activity in lung cancer. Mol. Biol. Rep. 2017, 44, 35-50. [CrossRef] [PubMed]

5. Mosselman, S.; Polman, J.; Dijkema, R. ER beta: Identification and characterization of a novel human estrogen receptor. FEBS Lett. 1996, 392, 49-53. [CrossRef]

6. Landis, S.H.; Murray, T.; Bolden, S.; Wingo, P.A. Cancer statistics, 1999. CA Cancer J. Clin. 1999, 49, 8-31. [CrossRef] [PubMed]

7. Centers for Disease Control (CDC); National Center for Chronic Disease Prevention and Health Promotion; Office on Smoking and Health. Women and Smoking: A Report of the Surgeon General; U.S. Public Health Service, Office of the Surgeon General: Washington, DC, USA, 2001. Available online: http://www.cdc.gov/tobacco (accessed on 20 May 2017).

8. Health Promotion Administration, Ministry of Health and Welfare, The Executive Yuan. Adult Smoking Behavior Survey. Available online: http:/ / www.hpa.gov.tw (accessed on 20 May 2017).

9. Hsu, L.H.; Chu, N.M.; Liu, C.C.; Tsai, S.Y.; You, D.L.; Ko, J.S.; Lu, M.C.; Feng, A.C. Sex-associated differences in non-small cell lung cancer in the new era: Is gender an independent prognostic factor? Lung Cancer 2009, 66, 262-267. [CrossRef] [PubMed]

10. Taiwan Cancer Registry. Cancer incidence and mortality rates in Taiwan. Available online: http://tcr.cph. ntu.edu.tw (accessed on 20 May 2017).

11. Hsu, L.H.; Liu, K.J.; Tsai, M.F.; Wu, C.R.; Feng, A.C.; Chu, N.M.; Kao, S.H. Estrogen adversely affects the prognosis of patients with lung adenocarcinoma. Cancer Sci. 2015, 106, 51-59. [CrossRef] [PubMed]

12. Zang, E.A.; Wynder, E.L. Differences in lung cancer risk between men and women: Examination of the evidence. J. Natl. Cancer Inst. 1996, 88, 183-192. [CrossRef] [PubMed]

13. Siegfried, J.M. Women and lung cancer: Does oestrogen play a role? Lancet Oncol. 2001, 2, 506-513. [CrossRef]

14. Carey, M.A.; Card, J.W.; Voltz, J.W.; Germolec, D.R.; Korach, K.S.; Zeldin, D.C. The impact of sex and sex hormones on lung physiology and disease: Lessons from animal studies. Am. J. Physiol. Lung Cell. Mol. Physiol. 2007, 293, L272-L278. [CrossRef] [PubMed]

15. Brandenberger, A.W.; Tee, M.K.; Lee, J.Y.; Chao, V.; Jaffe, R.B. Tissue distribution of estrogen receptors alpha (ER-alpha) and beta (ER-beta) mRNA in the midgestational human fetus. J. Clin. Endocrinol. Metab. 1997, 82, 3509-3512. [PubMed] 
16. Morani, A.; Barros, R.P.; Imamov, O.; Hultenby, K.; Arner, A.; Warner, M.; Gustafsson, J.A. Lung dysfunction causes systemic hypoxia in estrogen receptor beta knockout $\left(\right.$ ERbeta $\left.^{-/-}\right)$mice. Proc. Natl. Acad. Sci. USA 2006, 103, 7165-7169. [CrossRef] [PubMed]

17. Patrone, C.; Cassel, T.N.; Pettersson, K.; Piao, Y.S.; Cheng, G.; Ciana, P.; Maggi, A.; Warner, M.; Gustafsson, J.A.; Nord, M. Regulation of postnatal lung development and homeostasis by estrogen receptor beta. Mol. Cell. Biol. 2003, 23, 8542-8552. [CrossRef] [PubMed]

18. Zhang, G.; Liu, X.; Farkas, A.M.; Parwani, A.V.; Lathrop, K.L.; Lenzner, D.; Land, S.R.; Srinivas, H. Estrogen receptor beta functions through nongenomic mechanisms in lung cancer cells. Mol. Endocrinol. 2009, 23, 146-156. [CrossRef] [PubMed]

19. Stabile, L.P.; Siegfried, J.M. Estrogen receptor pathways in lung cancer. Curr. Oncol. Rep. 2004, 6, $259-267$. [CrossRef] [PubMed]

20. Kawai, H.; Ishii, A.; Washiya, K.; Konno, T.; Kon, H.; Yamaya, C.; Ono, I.; Minamiya, Y.; Ogawa, J. Estrogen receptor alpha and beta are prognostic factors in non-small cell lung cancer. Clin. Cancer Res. 2005, 11, 5084-5089. [CrossRef] [PubMed]

21. Schwartz, A.G.; Prysak, G.M.; Murphy, V.; Lonardo, F.; Pass, H.; Schwartz, J.; Brooks, S. Nuclear estrogen receptor beta in lung cancer: Expression and survival differences by sex. Clin. Cancer Res. 2005, 11, 7280-7287. [CrossRef] [PubMed]

22. Omoto, Y.; Kobayashi, Y.; Nishida, K.; Tsuchiya, E.; Eguchi, H.; Nakagawa, K.; Ishikawa, Y.; Yamori, T.; Iwase, H.; Fujii, Y.; et al. Expression, function, and clinical implications of the estrogen receptor beta in human lung cancers. Biochem. Biophys. Res. Commun. 2001, 285, 340-347. [CrossRef] [PubMed]

23. Stabile, L.P.; Davis, A.L.; Gubish, C.T.; Hopkins, T.M.; Luketich, J.D.; Christie, N.; Finkelstein, S.; Siegfried, J.M. Human non-small cell lung tumors and cells derived from normal lung express both estrogen receptor alpha and beta and show biological responses to estrogen. Cancer Res. 2002, 62, 2141-2150. [PubMed]

24. Ganti, A.K.; Sahmoun, A.E.; Panwalkar, A.W.; Tendulkar, K.K.; Potti, A. Hormone replacement therapy is associated with decreased survival in women with lung cancer. J. Clin. Oncol. 2006, 24, 59-63. [CrossRef] [PubMed]

25. Liu, Y.; Inoue, M.; Sobue, T.; Tsugane, S. Reproductive factors, hormone use and the risk of lung cancer among middle-aged never-smoking Japanese women: A large-scale population-based cohort study. Int. J. Cancer 2005, 117, 662-666. [CrossRef] [PubMed]

26. Niikawa, H.; Suzuki, T.; Miki, Y.; Suzuki, S.; Nagasaki, S.; Akahira, J.; Honma, S.; Evans, D.B.; Hayashi, S.; Kondo, T.; et al. Intratumoral estrogens and estrogen receptors in human non-small cell lung carcinoma. Clin. Cancer Res. 2008, 14, 4417-4426. [CrossRef] [PubMed]

27. Zhang, G.; Yanamala, N.; Lathrop, K.L.; Zhang, L.; Klein-Seetharaman, J.; Srinivas, H. Ligand-independent antiapoptotic function of estrogen receptor-beta in lung cancer cells. Mol. Endocrinol. 2010, 24, 1737-1747. [CrossRef] [PubMed]

28. Mah, V.; Marquez, D.; Alavi, M.; Maresh, E.L.; Zhang, L.; Yoon, N.; Horvath, S.; Bagryanova, L.; Fishbein, M.C.; Chia, D.; et al. Expression levels of estrogen receptor beta in conjunction with aromatase predict survival in non-small cell lung cancer. Lung Cancer 2011, 74, 318-325. [CrossRef] [PubMed]

29. Chlebowski, R.T.; Schwartz, A.G.; Wakelee, H.; Anderson, G.L.; Stefanick, M.L.; Manson, J.E.; Rodabough, R.J.; Chien, J.W.; Wactawski-Wende, J.; Gass, M.; et al. Women's Health Initiative, I. Oestrogen plus progestin and lung cancer in postmenopausal women (Women's Health Initiative trial): A post-hoc analysis of a randomised controlled trial. Lancet 2009, 374, 1243-1251. [CrossRef]

30. Slatore, C.G.; Chien, J.W.; Au, D.H.; Satia, J.A.; White, E. Lung cancer and hormone replacement therapy: Association in the vitamins and lifestyle study. J. Clin. Oncol. 2010, 28, 1540-1546. [CrossRef] [PubMed]

31. Schabath, M.B.; Wu, X.; Vassilopoulou-Sellin, R.; Vaporciyan, A.A.; Spitz, M.R. Hormone replacement therapy and lung cancer risk: A case-control analysis. Clin. Cancer Res. 2004, 10, 113-123. [CrossRef] [PubMed]

32. Schwartz, A.G.; Wenzlaff, A.S.; Prysak, G.M.; Murphy, V.; Cote, M.L.; Brooks, S.C.; Skafar, D.F.; Lonardo, F. Reproductive factors, hormone use, estrogen receptor expression and risk of non small-cell lung cancer in women. J. Clin. Oncol. 2007, 25, 5785-5792. [CrossRef] [PubMed]

33. Chen, K.Y.; Hsiao, C.F.; Chang, G.C.; Tsai, Y.H.; Su, W.C.; Perng, R.P.; Huang, M.S.; Hsiung, C.A.; Chen, C.J.; Yang, P.C.; et al. Hormone replacement therapy and lung cancer risk in Chinese. Cancer 2007, 110, 1768-1775. [CrossRef] [PubMed]

34. Huang, B.; Carloss, H.; Wyatt, S.W.; Riley, E. Hormone replacement therapy and survival in lung cancer in postmenopausal women in a rural population. Cancer 2009, 115, 4167-4175. [CrossRef] [PubMed] 
35. Ayeni, O.; Robinson, A. Hormone replacement therapy and outcomes for women with non-small-cell lung cancer: Can an association be confirmed? Curr. Oncol. 2009, 16, 21-25. [PubMed]

36. Chlebowski, R.T.; Anderson, G.L.; Manson, J.E.; Schwartz, A.G.; Wakelee, H.; Gass, M.; Rodabough, R.J.; Johnson, K.C.; Wactawski-Wende, J.; Kotchen, J.M.; et al. Lung cancer among postmenopausal women treated with estrogen alone in the Women's Health Initiative randomized trial. J. Natl. Cancer Inst. 2010, 102, 1413-1421. [CrossRef] [PubMed]

37. Bellahcene, A.; Castronovo, V.; Ogbureke, K.U.; Fisher, L.W.; Fedarko, N.S. Small integrin-binding ligand $N$-linked glycoproteins (SIBLINGs): Multifunctional proteins in cancer. Nat. Rev. Cancer 2008, 8, 212-226. [CrossRef] [PubMed]

38. Zirngibl, R.A.; Chan, J.S.; Aubin, J.E. Divergent regulation of the Osteopontin promoter by the estrogen receptor-related receptors is isoform- and cell context dependent. J. Cell Biochem. 2013, 114, 2356-2362. [CrossRef] [PubMed]

39. De Silva Rudland, S.; Martin, L.; Roshanlall, C.; Winstanley, J.; Leinster, S.; Platt-Higgins, A.; Carroll, J.; West, C.; Barraclough, R.; et al. Association of S100A4 and osteopontin with specific prognostic factors and survival of patients with minimally invasive breast cancer. Clin. Cancer Res. 2006, 12, 1192-1200. [CrossRef] [PubMed]

40. Chang, Y.S.; Kim, H.J.; Chang, J.; Ahn, C.M.; Kim, S.K.; Kim, S.K. Elevated circulating level of osteopontin is associated with advanced disease state of non-small cell lung cancer. Lung Cancer 2007, 57, 373-380. [CrossRef] [PubMed]

41. Cui, R.; Takahashi, F.; Ohashi, R.; Takahashi, F.; Ohashi, R.; Yoshioka, M.; Gu, T.; Tajima, K.; Unnoura, T.; Iwakami, S.; et al. Osteopontin is involved in the formation of malignant pleural effusion in lung cancer. Lung Cancer 2009, 63, 368-374. [CrossRef] [PubMed]

42. Bouchardy, C.; Benhamou, S.; Schaffar, R.; Verkooijen, H.M.; Fioretta, G.; Schubert, H.; Vinh-Hung, V.; Soria, J.C.; Vlastos, G.; Rapiti, E. Lung cancer mortality risk among breast cancer patients treated with anti-estrogens. Cancer 2011, 117, 1288-1295. [CrossRef] [PubMed]

43. Lother, S.A.; Harding, G.A.; Musto, G.; Navaratnam, S.; Pitz, M.W. Antiestrogen use and survival of women with non-small cell lung cancer in Manitoba, Canada. Horm. Cancer 2013, 4, 270-276. [CrossRef] [PubMed]

44. Hsu, L.H.; Feng, A.C.; Kao, S.H.; Liu, C.C.; Tsai, S.Y.; Shih, L.S.; Chu, N.M. Second primary lung cancers among breast cancer patients treated with anti-estrogens have a longer cancer-specific survival. Anticancer Res. 2015, 35, 1121-1127. [PubMed]

45. Del Prete, S.A.; Maurer, L.H.; Brinck-Johnsen, T.; Sorenson, G.D. 17-Beta-estradiol levels in patients with small cell carcinoma of the lung. J. Steroid Biochem. 1983, 18, 195-196. [CrossRef]

46. Sorenson, G.D.; Pettengill, O.S.; Brinck-Johnsen, T.; Cate, C.C.; Maurer, L.H. Hormone production by cultures of small-cell carcinoma of the lung. Cancer 1981, 47, 1289-1296. [CrossRef]

47. Baik, C.S.; Eaton, K.D. Estrogen signaling in lung cancer: An opportunity for novel therapy. Cancers 2012, 4 , 969-988. [CrossRef] [PubMed]

48. Kawai, H. Estrogen receptors as the novel therapeutic biomarker in non-small cell lung cancer. World J. Clin. Oncol. 2014, 5, 1020-1027. [CrossRef] [PubMed]

49. Siegfried, J.M.; Stabile, L.P. Estrongenic steroid hormones in lung cancer. Semin. Oncol. 2014, 41, 5-16. [CrossRef] [PubMed]

50. Leung, Y.K.; Mak, P.; Hassan, S.; Ho, S.M. Estrogen receptor (ER)-beta isoforms: A key to understanding ER-beta signaling. Proc. Natl. Acad. Sci. USA. 2006, 103, 13162-13167. [CrossRef] [PubMed]

51. Wu, C.T.; Chang, Y.L.; Shih, J.Y.; Lee, Y.C. The significance of estrogen receptor beta in 301 surgically treated non-small cell lung cancers. J. Thorac. Cardiovasc. Surg. 2005, 130, 979-986. [CrossRef] [PubMed]

52. Skov, B.G.; Fischer, B.M.; Pappot, H. Oestrogen receptor beta over expression in males with non-small cell lung cancer is associated with better survival. Lung Cancer 2008, 59, 88-94. [CrossRef] [PubMed]

53. Nose, N.; Sugio, K.; Oyama, T.; Nozoe, T.; Uramoto, H.; Iwata, T.; Onitsuka, T.; Yasumoto, K. Association between estrogen receptor-beta expression and epidermal growth factor receptor mutation in the postoperative prognosis of adenocarcinoma of the lung. J. Clin. Oncol. 2009, 27, 411-417. [CrossRef] [PubMed]

54. Raso, M.G.; Behrens, C.; Herynk, M.H.; Liu, S.; Prudkin, L.; Ozburn, N.C.; Woods, D.M.; Tang, X.; Mehran, R.J.; Moran, C.; et al. Immunohistochemical expression of estrogen and progesterone receptors identifies a subset of NSCLCs and correlates with EGFR mutation. Clin. Cancer Res. 2009, 15, 5359-5368. [CrossRef] [PubMed] 
55. Stabile, L.P.; Dacic, S.; Land, S.R.; Lenzner, D.E.; Dhir, R.; Acquafondata, M.; Landreneau, R.J.; Grandis, J.R.; Siegfried, J.M. Combined analysis of estrogen receptor beta-1 and progesterone receptor expression identifies lung cancer patients with poor outcome. Clin. Cancer Res. 2011, 17, 154-164. [CrossRef] [PubMed]

56. Rouquette, I.; Lauwers-Cances, V.; Allera, C.; Brouchet, L.; Milia, J.; Nicaise, Y.; Laurent, J.; Delisle, M.B.; Favre, G.; Didier, A.; et al. Characteristics of lung cancer in women: Importance of hormonal and growth factors. Lung Cancer 2012, 76, 280-285. [CrossRef] [PubMed]

57. Rades, D.; Setter, C.; Dahl, O.; Schild, S.E.; Noack, F. The prognostic impact of tumor cell expression of estrogen receptor-alpha, progesterone receptor, and androgen receptor in patients irradiated for nonsmall cell lung cancer. Cancer 2012, 118, 157-163. [CrossRef] [PubMed]

58. Karlsson, C.; Helenius, G.; Fernandes, O.; Karlsson, M.G. Oestrogen receptor beta in NSCLC-Prevalence, proliferative influence, prognostic impact and smoking. Acta Pathol. Microbiol. Immunol. Scand. 2012, 120, 451-458. [CrossRef] [PubMed]

59. Navaratnam, S.; Skliris, G.; Qing, G.; Banerji, S.; Badiani, K.; Tu, D.; Bradbury, P.A.; Leighl, N.B.; Shepherd, F.A.; Nowatzki, J.; et al. Differential role of estrogen receptor beta in early versus metastatic non-small cell lung cancer. Horm. Cancer 2012, 3, 93-100. [CrossRef] [PubMed]

60. Liu, Z.; Liao, Y.; Tang, H.; Chen, G. The expression of estrogen receptors beta2, 5 identifies and is associated with prognosis in non-small cell lung cancer. Endocrine 2013, 44, 517-524. [CrossRef] [PubMed]

61. Kadota, K.; Eguchi, T.; Villena-Vargas, J.; Woo, K.M.; Sima, C.S.; Jones, D.R.; Travis, W.D.; Adusumilli, P.S. Nuclear estrogen receptor-alpha expression is an independent predictor of recurrence in male patients with pT1aN0 lung adenocarcinomas, and correlates with regulatory T-cell infiltration. Oncotarget 2015, 6, 27505-27518. [CrossRef] [PubMed]

62. Liu, C.M.; Chiu, K.L.; Chen, T.S.; Chang, S.M.; Yang, S.Y.; Chen, L.H.; Ni, Y.L.; Sher, Y.P.; Yu, S.L.; Ma, W.L. Potential therapeutic benefit of combining gefitinib and tamoxifen for treating advanced lung adenocarcinoma. Biomed. Res. Int. 2015, 2015, 642041. [CrossRef] [PubMed]

63. Skjefstad, K.; Grindstad, T.; Khanehkenari, M.R.; Richardsen, E.; Donnem, T.; Kilvaer, T.; Andersen, S.; Bremnes, R.M.; Busund, L.T.; Al-Saad, S. Prognostic relevance of estrogen receptor alpha, beta and aromatase expression in non-small cell lung cancer. Steroids 2016, 113, 5-13. [CrossRef] [PubMed]

64. Tanaka, K.; Shimizu, K.; Kakegawa, S.; Ohtaki, Y.; Nagashima, T.; Kaira, K.; Horiguchi, J.; Oyama, T.; Takeyoshi, I. Prognostic significance of aromatase and estrogen receptor beta expression in EGFR wild-type lung adenocarcinoma. Am. J. Transl. Res. 2016, 8, 81-97. [PubMed]

65. Li, W.; Tse, L.A.; Wang, F. Prognostic value of estrogen receptors mRNA expression in non-small cell lung cancer: A systematic review and meta-analysis. Steroids 2015, 104, 129-136. [CrossRef] [PubMed]

66. Ma, L.; Zhan, P.; Liu, Y.; Zhou, Z.; Zhu, Q.; Miu, Y.; Wang, X.; Jin, J.; Li, Q.; Lv, T.; et al. Prognostic value of the expression of estrogen receptor beta in patients with non-small cell lung cancer: A meta-analysis. Transl. Lung Cancer Res. 2016, 5, 202-207. [CrossRef] [PubMed]

67. Wang, Z.; Li, Z.; Ding, X.; Shen, Z.; Liu, Z.; An, T.; Duan, J.; Zhong, J.; Wu, M.; Zhao, J.; et al. ERbeta localization influenced outcomes of EGFR-TKI treatment in NSCLC patients with EGFR mutations. Sci. Rep. 2015, 5, 11392. [CrossRef] [PubMed]

68. Liao, T.L.; Tzeng, C.R.; Yu, C.L.; Wang, Y.P.; Kao, S.H. Estrogen receptor-beta in mitochondria: Implications for mitochondrial bioenergetics and tumorigenesis. Ann. N. Y. Acad. Sci. 2015, 1350, 52-60. [CrossRef] [PubMed]

69. Xie, Q.; Huang, Z.; Liu, Y.; Liu, X.; Huang, L. Mitochondrial estrogen receptor beta inhibits non-small cell lung cancer cell apoptosis via interaction with Bad. Nan Fang Yi Ke Da Xue Xue Bao 2015, 35, 98-102. [PubMed]

70. Jacenik, D.; Cygankiewicz, A.I.; Krajewska, W.M. The G protein-coupled estrogen receptor as a modulator of neoplastic transformation. Mol. Cell. Endocrinol. 2016, 429, 10-18. [CrossRef] [PubMed]

71. Konings, G.F.; Reynaert, N.L.; Delvoux, B.; Verhamme, F.M.; Bracke, K.R.; Brusselle, G.G.; Romano, A.; Vernooy, J.H. Increased levels of enzymes involved in local estradiol synthesis in chronic obstructive pulmonary disease. Mol. Cell. Endocrinol. 2017, 443, 23-31. [CrossRef] [PubMed]

72. Revankar, C.M.; Cimino, D.F.; Sklar, L.A.; Arterburn, J.B.; Prossnitz, E.R. A transmembrane intracellular estrogen receptor mediates rapid cell signaling. Science 2005, 307, 1625-1630. [CrossRef] [PubMed]

73. Sakamoto, H.; Matsuda, K.; Hosokawa, K.; Nishi, M.; Morris, J.F.; Prossnitz, E.R.; Kawata, M. Expression of $\mathrm{G}$ protein-coupled receptor-30, a G protein-coupled membrane estrogen receptor, in oxytocin neurons of the rat paraventricular and supraoptic nuclei. Endocrinology 2007, 148, 5842-5850. [CrossRef] [PubMed] 
74. Jala, V.R.; Radde, B.N.; Haribabu, B.; Klinge, C.M. Enhanced expression of G-protein coupled estrogen receptor (GPER/GPR30) in lung cancer. BMC Cancer 2012, 12, 624. [CrossRef] [PubMed]

75. Liu, C.; Liao, Y.; Fan, S.; Tang, H.; Jiang, Z.; Zhou, B.; Xiong, J.; Zhou, S.; Zou, M.; Wang, J. G protein-coupled estrogen receptor (GPER) mediates NSCLC progression induced by 17beta-estradiol (E2) and selective agonist G1. Med. Oncol. 2015, 32, 104. [CrossRef] [PubMed]

76. Lucas, T.F.; Siu, E.R.; Esteves, C.A.; Monteiro, H.P.; Oliveira, C.A.; Porto, C.S.; Lazari, M.F. 17 beta-estradiol induces the translocation of the estrogen receptors ESR1 and ESR2 to the cell membrane, MAPK3/1 phosphorylation and proliferation of cultured immature rat Sertoli cells. Biol. Reprod. 2008, 78, 101-114. [CrossRef] [PubMed]

77. Honma, N.; Hosoi, T.; Arai, T.; Takubo, K. Estrogen and cancers of the colorectum, breast, and lung in postmenopausal women. Pathol. Int. 2015, 65, 451-459. [CrossRef] [PubMed]

78. Ikeda, K.; Shiraishi, K.; Yoshida, A.; Shinchi, Y.; Sanada, M.; Motooka, Y.; Fujino, K.; Mori, T.; Suzuki, M. Synchronous multiple lung adenocarcinomas: Estrogen concentration in peripheral lung. PLoS ONE 2016, 11, e0160910. [CrossRef] [PubMed]

79. Hsu, L.H.; Hsu, P.C.; Liao, T.L.; Feng, A.C.; Chu, N.M.; Kao, S.H. Pleural fluid osteopontin, vascular endothelial growth factor, and urokinase-type plasminogen activator levels as predictors of pleurodesis outcome and prognosticators in patients with malignant pleural effusion: A prospective cohort study. BMC Cancer 2016, 16, 463. [CrossRef] [PubMed]

80. Yatabe, Y.; Mitsudomi, T.; Takahashi, T. TTF-1 expression in pulmonary adenocarcinomas. Am. J. Surg. Pathol. 2002, 26, 767-773. [CrossRef] [PubMed]

81. Shanzhi, W.; Yiping, H.; Ling, H.; Jianming, Z.; Qiang, L. The relationship between TTF-1 expression and EGFR mutations in lung adenocarcinomas. PLoS ONE 2014, 9, e95479. [CrossRef] [PubMed]

82. Chung, K.P.; Huang, Y.T.; Chang, Y.L.; Yu, C.J.; Yang, C.H.; Chang, Y.C.; Shih, J.Y.; Yang, P.C. Clinical significance of thyroid transcription factor-1 in advanced lung adenocarcinoma under epidermal growth factor receptor tyrosine kinase inhibitor treatment. Chest 2012, 141, 420-428. [CrossRef] [PubMed]

83. Lau, S.K.; Chu, P.G.; Weiss, L.M. Immunohistochemical expression of estrogen receptor in pulmonary adenocarcinoma. Appl. Immunohistochem. Mol. Morphol. 2006, 14, 83-87. [CrossRef] [PubMed]

84. Greiser, C.M.; Greiser, E.M.; Doren, M. Menopausal hormone therapy and risk of lung cancer-Systematic review and meta-analysis. Maturitas 2010, 65, 198-204. [CrossRef] [PubMed]

85. Chlebowski, R.T.; Wakelee, H.; Pettinger, M.; Rohan, T.; Liu, J.; Simon, M.; Tindle, H.; Messina, C.; Johnson, K.; Schwartz, A.; et al. Estrogen plus progestin and lung cancer: Follow-up of the Women's Health Initiative randomized trial. Clin. Lung Cancer 2016, 17, 10-17. [CrossRef] [PubMed]

86. Jiang, X.; Shapiro, D.J. The immune system and inflammation in breast cancer. Mol. Cell. Endocrinol. 2014, 382, 673-682. [CrossRef] [PubMed]

87. Grivennikov, S.I.; Greten, F.R.; Karin, M. Immunity, inflammation, and cancer. Cell 2010, 140, 883-899. [CrossRef] [PubMed]

88. Miki, Y.; Suzuki, T.; Abe, K.; Suzuki, S.; Niikawa, H.; Iida, S.; Hata, S.; Akahira, J.; Mori, K.; Evans, D.B.; et al. Intratumoral localization of aromatase and interaction between stromal and parenchymal cells in the non-small cell lung carcinoma microenvironment. Cancer Res. 2010, 70, 6659-6669. [CrossRef] [PubMed]

89. Stabile, L.P.; Rothstein, M.E.; Cunningham, D.E.; Land, S.R.; Dacic, S.; Keohavong, P.; Siegfried, J.M. Prevention of tobacco carcinogen-induced lung cancer in female mice using antiestrogens. Carcinogenesis 2012, 33, 2181-2189. [CrossRef] [PubMed]

90. Mah, V.; Seligson, D.B.; Li, A.; Marquez, D.C.; Wistuba, I.I.; Elshimali, Y.; Fishbein, M.C.; Chia, D.; Pietras, R.J.; Goodglick, L. Aromatase expression predicts survival in women with early-stage non small cell lung cancer. Cancer Res. 2007, 67, 10484-10490. [CrossRef] [PubMed]

91. Weinberg, O.K.; Marquez-Garban, D.C.; Fishbein, M.C.; Goodglick, L.; Garban, H.J.; Dubinett, S.M.; Pietras, R.J. Aromatase inhibitors in human lung cancer therapy. Cancer Res. 2005, 65, 11287-11291. [CrossRef] [PubMed]

92. Marquez-Garban, D.C.; Chen, H.W.; Goodglick, L.; Fishbein, M.C.; Pietras, R.J. Targeting aromatase and estrogen signaling in human non-small cell lung cancer. Ann. N. Y. Acad. Sci. 2009, 1155, 194-205. [CrossRef] [PubMed]

93. Hamilton, D.H.; Griner, L.M.; Keller, J.M.; Hu, X.; Southall, N.; Marugan, J.; David, J.M.; Ferrer, M.; Palena, C. Targeting estrogen receptor signaling with fulvestrant enhances immune and chemotherapy-mediated cytotoxicity of human lung cancer. Clin. Cancer Res. 2016, 22, 6204-6216. [CrossRef] [PubMed] 
94. Swedenborg, E.; Power, K.A.; Cai, W.; Pongratz, I.; Ruegg, J. Regulation of estrogen receptor beta activity and implications in health and disease. Cell. Mol. Life Sci. 2009, 66, 3873-3894. [CrossRef] [PubMed]

95. Levin, E.R. Bidirectional signaling between the estrogen receptor and the epidermal growth factor receptor. Mol. Endocrinol. 2003, 17, 309-317. [CrossRef] [PubMed]

96. Kato, S.; Endoh, H.; Masuhiro, Y.; Kitamoto, T.; Uchiyama, S.; Sasaki, H.; Masushige, S.; Gotoh, Y.; Nishida, E.; Kawashima, H.; et al. Activation of the estrogen receptor through phosphorylation by mitogen-activated protein kinase. Science 1995, 270, 1491-1494. [CrossRef] [PubMed]

97. Marquez-Garban, D.C.; Chen, H.W.; Fishbein, M.C.; Goodglick, L.; Pietras, R.J. Estrogen receptor signaling pathways in human non-small cell lung cancer. Steroids 2007, 72, 135-143. [CrossRef] [PubMed]

98. Zhao, X.Z.; Liu, Y.; Zhou, L.J.; Wang, Z.Q.; Wu, Z.H.; Yang, X.Y. Role of estrogen in lung cancer based on the estrogen receptor-epithelial mesenchymal transduction signaling pathways. OncoTargets Ther. 2015, 8, 2849-2863. [CrossRef] [PubMed]

99. Fan, S.; Liao, Y.; Liu, C.; Huang, Q.; Liang, H.; Ai, B.; Fu, S.; Zhou, S. Estrogen promotes tumor metastasis via estrogen receptor beta-mediated regulation of matrix-metalloproteinase-2 in non-small cell lung cancer. Oncotarget 2017. [CrossRef] [PubMed]

100. Siegfried, J.M.; Farooqui, M.; Rothenberger, N.J.; Dacic, S.; Stabile, L.P. Interaction between the estrogen receptor and fibroblast growth factor receptor pathways in non-small cell lung cancer. Oncotarget 2017, 8, 24063-24076. [CrossRef] [PubMed]

101. Stabile, L.P.; Lyker, J.S.; Gubish, C.T.; Zhang, W.; Grandis, J.R.; Siegfried, J.M. Combined targeting of the estrogen receptor and the epidermal growth factor receptor in non-small cell lung cancer shows enhanced antiproliferative effects. Cancer Res. 2005, 65, 1459-1470. [CrossRef] [PubMed]

102. Pietras, R.J.; Marquez, D.C.; Chen, H.W.; Tsai, E.; Weinberg, O.; Fishbein, M. Estrogen and growth factor receptor interactions in human breast and non-small cell lung cancer cells. Steroids 2005, 70, 372-381. [CrossRef] [PubMed]

103. Deng, F.; Li, M.; Shan, W.L.; Qian, L.T.; Meng, S.P.; Zhang, X.L.; Wang, B.L. Correlation between epidermal growth factor receptor mutations and the expression of estrogen receptor-beta in advanced non-small cell lung cancer. Oncol. Lett. 2017, 13, 2359-2365. [PubMed]

104. Kawaguchi, T.; Koh, Y.; Ando, M.; Ito, N.; Takeo, S.; Adachi, H.; Tagawa, T.; Kakegawa, S.; Yamashita, M.; Kataoka, K.; et al. Prospective analysis of oncogenic driver mutations and environmental factors: Japan Molecular Epidemiology For Lung Cancer Study. J. Clin. Oncol. 2016, 34, 2247-2257. [CrossRef] [PubMed]

105. Dubey, S.; Siegfried, J.M.; Traynor, A.M. Non-small-cell lung cancer and breast carcinoma: Chemotherapy and beyond. Lancet Oncol. 2006, 7, 416-424. [CrossRef]

106. Giovannini, M.; Belli, C.; Villa, E.; Gregorc, V. Estrogen receptor and epidermal growth factor receptor as targets for dual lung cancer therapy: Not just a case? J. Thorac. Oncol. 2008, 3, 684-685. [CrossRef] [PubMed]

107. Traynor, A.M.; Schiller, J.H.; Stabile, L.P.; Kolesar, J.M.; Eickhoff, J.C.; Dacic, S.; Hoang, T.; Dubey, S.; Marcotte, S.M.; Siegfried, J.M. Pilot study of gefitinib and fulvestrant in the treatment of post-menopausal women with advanced non-small cell lung cancer. Lung Cancer 2009, 64, 51-59. [CrossRef] [PubMed]

108. ClinicalTrials.gov, U.S. National Institutes of Health. Available online: http://www.clinicaltrial.gov/ (accessed on 11 June 2017).

109. Iida, S.; Kakinuma, H.; Miki, Y.; Abe, K.; Sakurai, M.; Suzuki, S.; Niikawa, H.; Akahira, J.; Suzuki, T.; Sasano, H. Steroid sulphatase and oestrogen sulphotransferase in human non-small-cell lung carcinoma. Br. J. Cancer 2013, 108, 1415-1424. [CrossRef] [PubMed]

110. Wang, L.J.; Li, J.; Hao, F.R.; Yuan, Y.; Li, J.Y.; Lu, W.; Zhou, T.Y. Dexamethasone suppresses the growth of human non-small cell lung cancer via inducing estrogen sulfotransferase and inactivating estrogen. Acta Pharmacol. Sin. 2016, 37, 845-856. [CrossRef] [PubMed]

111. Chen, X.Q.; Zheng, L.X.; Li, Z.Y.; Lin, T.Y. Clinicopathological significance of oestrogen receptor expression in non-small cell lung cancer. J. Int. Med. Res. 2017, 45, 51-58. [CrossRef] [PubMed]

112. Inamura, K.; Takeuchi, K.; Togashi, Y.; Hatano, S.; Ninomiya, H.; Motoi, N.; Mun, M.Y.; Sakao, Y.; Okumura, S.; Nakagawa, K.; et al. EML4-ALK lung cancers are characterized by rare other mutations, a TTF-1 cell lineage, an acinar histology, and young onset. Mod. Pathol. 2009, 22, 508-515. [CrossRef] [PubMed]

113. Inamura, K.; Ninomiya, H.; Ishikawa, Y.; Matsubara, O. Is the epidermal growth factor receptor status in lung cancers reflected in clinicopathologic features? Arch. Pathol. Lab. Med. 2010, 134, 66-72. [PubMed] 
114. Lehtio, J.; De Petris, L. Lung cancer proteomics, clinical and technological considerations. J. Proteom. 2010, 73, 1851-1863. [CrossRef] [PubMed]

115. Indovina, P.; Marcelli, E.; Pentimalli, F.; Tanganelli, P.; Tarro, G.; Giordano, A. Mass spectrometry-based proteomics: The road to lung cancer biomarker discovery. Mass Spectrom. Rev. 2013, 32, 129-142. [CrossRef] [PubMed]

116. Hagemann, I.S.; Devarakonda, S.; Lockwood, C.M.; Spencer, D.H.; Guebert, K.; Bredemeyer, A.J.; Al-Kateb, H.; Nguyen, T.T.; Duncavage, E.J.; Cottrell, C.E.; et al. Clinical next-generation sequencing in patients with non-small cell lung cancer. Cancer 2015, 121, 631-639. [CrossRef] [PubMed]

117. Yang, S.Y.; Yang, T.Y.; Chen, K.C.; Li, Y.J.; Hsu, K.H.; Tsai, C.R.; Chen, C.Y.; Hsu, C.P.; Hsia, J.Y.; Chuang, C.Y.; et al. EGFR L858R mutation and polymorphisms of genes related to estrogen biosynthesis and metabolism in never-smoking female lung adenocarcinoma patients. Clin. Cancer Res. 2011, 17, 2149-2158. [CrossRef] [PubMed]

118. Chen, K.Y.; Hsiao, C.F.; Chang, G.C.; Tsai, Y.H.; Su, W.C.; Chen, Y.M.; Huang, M.S.; Hsiung, C.A.; Chen, C.J.; Yang, P.C. EGFR polymorphisms, hormone replacement therapy and lung adenocarcinoma risk: Analysis from a genome-wide association study in never-smoking women. Carcinogenesis 2013, 34, 612-619. [CrossRef] [PubMed]

119. Chen, K.Y.; Hsiao, C.F.; Chang, G.C.; Tsai, Y.H.; Su, W.C.; Chen, Y.M.; Huang, M.S.; Tsai, F.Y.; Jiang, S.S.; Chang, I.S.; et al. Estrogen receptor gene polymorphisms and lung adenocarcinoma risk in never-smoking women. J. Thorac. Oncol. 2015, 10, 1413-1420. [CrossRef] [PubMed]

120. Belous, A.R.; Hachey, D.L.; Dawling, S.; Roodi, N.; Parl, F.F. Cytochrome P450 1B1-mediated estrogen metabolism results in estrogen-deoxyribonucleoside adduct formation. Cancer Res. 2007, 67, 812-817. [CrossRef] [PubMed]

121. Meireles, S.I.; Esteves, G.H.; Hirata, R., Jr.; Peri, S.; Devarajan, K.; Slifker, M.; Mosier, S.L.; Peng, J.; Vadhanam, M.V.; Hurst, H.E.; et al. Early changes in gene expression induced by tobacco smoke: Evidence for the importance of estrogen within lung tissue. Cancer Prev. Res. 2010, 3, 707-717. [CrossRef] [PubMed]

122. Peng, J.; Xu, X.; Mace, B.E.; Vanderveer, L.A.; Workman, L.R.; Slifker, M.J.; Sullivan, P.M.; Veenstra, T.D.; Clapper, M.L. Estrogen metabolism within the lung and its modulation by tobacco smoke. Carcinogenesis 2013, 34, 909-915. [CrossRef] [PubMed]

123. Olea, N.; Pazos, P.; Exposito, J. Inadvertent exposure to xenoestrogens. Eur. J. Cancer Prev. 1998, 7, S17-S23. [CrossRef] [PubMed]

124. Swedenborg, E.; Ruegg, J.; Makela, S.; Pongratz, I. Endocrine disruptive chemicals: Mechanisms of action and involvement in metabolic disorders. J. Mol. Endocrinol. 2009, 43, 1-10. [CrossRef] [PubMed]

125. Swedenborg, E.; Pongratz, I.; Gustafsson, J.A. Endocrine disruptors targeting ERbeta function. Int. J. Androl. 2010, 33, 288-297. [CrossRef] [PubMed]

126. Fucic, A.; Gamulin, M.; Ferencic, Z.; Rokotov, D.S.; Katic, J.; Bartonova, A.; Lovasic, I.B.; Merlo, D.F. Lung cancer and environmental chemical exposure: A review of our current state of knowledge with reference to the role of hormones and hormone receptors as an increased risk factor for developing lung cancer in man. Toxicol. Pathol. 2010, 38, 849-855. [CrossRef] [PubMed]

127. Fucic, A.; Gamulin, M.; Ferencic, Z.; Katic, J.; von Krauss, M.K.; Bartonova, A.; Merlo, D.F. Environmental exposure to xenoestrogens and oestrogen related cancers: Reproductive system, breast, lung, kidney, pancreas, and brain. Environ. Health 2012, 11, S8. [CrossRef] [PubMed]

128. Hsu, K.H.; Ho, C.C.; Hsai, T.C.; Tseng, J.S.; Su, K.Y.; Wu, M.F.; Chiu, K.L.; Yang, T.Y.; Chen, K.C.; Ooi, H.; et al. Identification of five driver gene mutations in patients with treatment-naive lung adenocarcinoma in Taiwan. PLoS ONE 2015, 10, e0120852. [CrossRef] [PubMed]

129. Garon, E.B.; Pietras, R.J.; Finn, R.S.; Kamranpour, N.; Pitts, S.; Marquez-Garban, D.C.; Desai, A.J.; Dering, J.; Hosmer, W.; von Euw, E.M.; et al. Antiestrogen fulvestrant enhances the antiproliferative effects of epidermal growth factor receptor inhibitors in human non-small-cell lung cancer. J. Thorac. Oncol. 2013, 8, 270-278. [CrossRef] [PubMed]

130. Patel, J.D.; Gray, R.G.; Stewart, J.A.; Skinner, H.G.; Schiller, J.H. Tamoxifen does not reduce the risk of lung cancer in women. J. Clin. Oncol. 2005, 23, s7212. [CrossRef]

(C) 2017 by the authors. Licensee MDPI, Basel, Switzerland. This article is an open access article distributed under the terms and conditions of the Creative Commons Attribution (CC BY) license (http:/ / creativecommons.org/licenses/by/4.0/). 